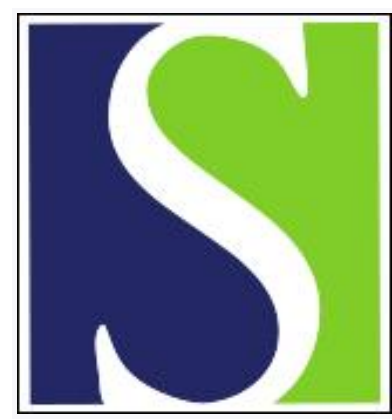

Scand J Work Environ Health 2011;37(5):394-401

https://doi.org/10.5271/sjweh.3160

Published online: 21 Mar 2011, Issue date: Sep 2011

Risk factors for de Quervain's disease in a French working population

by Petit Le Manac'h A, Roquelaure Y, Ha C, Bodin J, Meyer G, Bigot F, Veaudor M, Descatha A, Goldberg M, Imbernon E

Affiliation: Université d'Angers, faculté de médecine, laboratoire d'ergonomie et d'epidémiologie en santé au travail, CHU, F-49933 Angers Cedex, France. aupetit@chu-angers.fr

Refers to the following texts of the Journal: 1991;17(1):32-37 1979;5 suppl 3:48-55 1983;9(3):283-290 1995;21(6):450-459 2009;35(2):113-126

Key terms: de Quervain's disease; France; personal factor; physical exposure; risk factor; work; working population

This article in PubMed: www.ncbi.nlm.nih.gov/pubmed/21431276

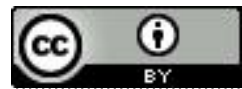




\title{
Risk factors for de Quervain's disease in a French working population
}

\author{
by Audrey Petit Le Manac'h, MD, ${ }^{1}$ Yves Roquelaure, MD, PhD, ${ }^{1}$ Catherine Ha, MD, PhD, ${ }^{2}$ Julie Bodin, \\ MSc, ${ }^{1}$ Geraldine Meyer, MD, ${ }^{1}$ Frederic Bigot, MSc, ${ }^{1}$ Martin Veaudor, MSc, ${ }^{1}$ Alexis Descatha, MD, PhD, ${ }^{3}$ \\ Marcel Goldberg, MD, PhD, ${ }^{3}$ Ellen Imbernon, MD, PhD ${ }^{2}$
}

\begin{abstract}
Petit Le Manac'h A, Roquelaure Y, Ha C, Bodin J, Meyer G, Bigot F, Veaudor M, Descatha A, Goldberg M, Imbernon E. Risk factors for de Quervain's disease in a French working population. Scand J Work Environ Health 2011;37(5):394401. doi:10.5271/sjweh.3160
\end{abstract}

\begin{abstract}
Objective De Quervain's disease (DQD) is a significant cause of musculoskeletal pain among workers. The aim of this study was to assess the relative importance of personal and occupational risk factors for DQD in a working population.

Methods A total of 3710 workers from a French region were randomly included in the cross-sectional study between 2002-2005. There were 45 subjects with DQD (of these, 5 subjects had a bilateral condition), diagnosed by 83 trained occupational physicians performing a standardized physical examination. Individual factors and work exposure were assessed by a standardized physical and a self-administered questionnaire. Statistical associations between DQD and individual and occupational factors were analyzed using logistic regression modeling in the whole sample and among women.
\end{abstract}

\begin{abstract}
Results The prevalence rates of uni- or bilateral DQD for the whole, male and female working populations were $1.2 \%$ [95\% confidence interval $(95 \%$ CI $) 0.9-1.6], 0.6 \%$ (95\% CI $0.3-0.9)$ and $2.1 \%$ (95\% CI 1.4-2.8), respectively. Personal risk factors for DQD were mainly age (1.1 for 1-year increase in age) and female gender [odds ratio (OR) 4.9, 95\% CI 2.4-10.1]. Work-related factors were workpace dependent on (i) technical organization (OR 2.0, 95\% CI 1.0-4.0), (ii) repeated or sustained wrist bending in extreme posture (OR 2.6, 95\% CI 1.3-5.3), and (iii) repeated movements associated with the twisting or driving of screws (OR 3.4, 95\% CI 1.7-7.1). No association was found with psychosocial factors.
\end{abstract}

Conclusions Personal and work-related factors were associated with DQD in the working population; wrist bending and movements associated with the twisting or driving of screws were the most significant of the workrelated factors.

Key terms France; personal factor; physical exposure; work.

De Quervain's disease (DQD) is a stenosing tenosynovitis of the tendons and synovial sheaths of the abductor pollicis longus and the extensor pollici brevis muscles that are involved in prehensile movements of the thumb. DQD causes pain and swelling near the base of the thumb during pinching, grasping, and other movements involving the thumb, and radial inclination of the wrist (1). DQD is most often diagnosed among middle-aged women with a history of repetitive hand-wrist movements during work or hobbies, but sometimes occurs among young mothers carrying babies with the wrist held in flexion and ulnar deviation and the thumb in extension (2).

The potential work-relatedness of DQD has been recognized for many years in various occupations (3), but epidemiological information on this disorder in working populations is still scant. A wide range of prevalence of DQD $(0.7-36 \%)$ has been reported in working populations, depending on the definition used and the populations involved (4-11). An incidence of 0.6 per 1000 person-years among men and 2.8 per 1000 person-years among women was recently reported in a large population of young US military personnel (12). Although not caused only by work, DQD (1415 cases in 2007 ) represents about $8 \%$ of the musculoskeletal disorders of the hand-wrist region receiving compensation each year in France.

1 Université d'Angers, faculté de médecine, laboratoire d'ergonomie et d'epidémiologie en santé au travail (LEEST), Angers, France.

2 Département santé travail, Institut de Veille Sanitaire (DST-InVS), Saint-Maurice, France.

3. Institut National de la Santé et de la Recherche Médicale (INSERM), U687, Villejuif, France.

Correspondence to : Audrey Petit Le Manac'h, Université d'Angers, faculté de médecine, LEEST, CHU, F-49933 Angers Cedex, France. [E-mail: aupetit@chu-angers.fr] 
Several combinations of individual, work, and psychosocial factors related to hand-wrist musculoskeletal disorders (MSD) have been identified (13-18), but few studies have specifically focused on DQD. The main work-related factors reported have been repetitive movements, forceful manual exertion, sustained awkward posture of the wrist, and combinations of these factors (13, $14,16,18)$. Most studies have involved highly exposed workers, and the relative importance of personal and work-related factors in DQD need to be better characterized in a more general working population characterized by various levels of exposure to work-related constraints.

The surveillance program for MSD implemented in the Pays de la Loire region by the National Institute for Public Health Surveillance since 2002 has allowed us to study the risk factors for DQD among workers exposed to various levels of work-related constraints $(9,19)$. For the first two years of the surveillance program, we reported a prevalence rate for DQD of $0.7 \%$ [ $95 \%$ confidence interval $(95 \% \mathrm{CI}) 0.3-1.1]$ among men and $2.1 \%$ (95\% CI 1.2-2.9) among women (9). Using the results of epidemiological surveillance over a three-year period, our aim in this study was to assess the prevalence and relative importance of personal and occupational risk factors for DQD in a large sample of workers representative of the working population of the region.

\section{Methods}

\section{Study population and design}

This cross-sectional study was conducted in the Loire Valley region of West-Central France. The economic structure of the region $(5 \%$ of the French working population) is diversified and similar to that of most French regions.

Population. All French salaried workers, including temporary and part-time workers, undergo a mandatory health examination by a qualified occupational physician (OP) in charge of the medical surveillance of a group of companies. A total of $83 \mathrm{OP}$, representative of the region's OP, participated in the study. Subjects were randomly selected from workers undergoing a mandatory, regularly scheduled health examination between April 2002 and April 2005. During the study period, only one examination per subject was performed. All OP were trained by the investigators to include workers randomly and perform a standardized physical examination.

The study population comprised 3710 workers [2161 men (58\%) and 1549 women (42\%), mean age 38.7 years, standard deviation (SD) 10.3 years] representing about $3.4 \%$ of the regional workforce. Comparison of their socioeconomic status with the last available French census (1999) (http://www.insee.fr) showed no major differences for either gender. Subjects worked mainly in the service industries (59\%), the meat and manufacturing industries (34\%), and more rarely in the construction $(6 \%)$ and agriculture (1.5\%) sectors. Overall, the distribution of occupations was close to that of the regional workforce, except for the rare occupations not surveyed by OP (eg, shopkeepers and independent workers). Men were mainly skilled and unskilled blue-collar workers (56\%), intermediate occupations and technicians (25\%), and managers and professionals (10\%). Most women were low-grade, white-collar workers (52\%), skilled and unskilled blue-collar workers (24\%), and technicians and associate professionals (19\%). Length of service in the current job was high for the majority of workers, regardless of gender. Length of service was $>10$ years in $41 \%$ of cases, $>2$ years in $73 \%$ of cases, and $>1$ year in $91 \%$ of cases.

Outcomes. The presence of non-specific, upper-extremity pain during the last 12 months and the preceding 7 days was identified using the "Nordic-style" questionnaire (9). A mannequin was used to denote the handwrist region. In cases of hand-wrist symptoms occurring during the past 12 months, the physician performed a physical examination using a standardized clinical procedure that strictly applied the methodology and clinical tests of the "European consensus criteria document" (20) for DQD and the five other specific upper-extremity MSD surveyed (ie, rotator cuff syndrome, lateral epicondylitis, ulnar tunnel syndrome, carpal tunnel syndrome, and flexor-extensor peritendinitis or tenosynovitis of the forearm-wrist region). [See Roquelaure et al (21) for details]. DQD was diagnosed if (i) there was intermittent pain or tenderness localized over the radial side of the wrist, possibly radiating proximally to the forearm or distally to the thumb, and present currently or for $\geq 4$ days in the preceding 7 days and (ii) Finkelstein's test was positive, with distinct right/left difference. This test was performed according the recommendations of Sluiter et al (20) with the patient sitting with the forearm resting on a table in a pronated position and the wrist extended at about $20^{\circ}$. The fist was clenched with the thumb tucked in the fingers. One of the OP's hands stabilized the distal forearm from the ulnar side and the other was placed around the fist from the radial side and gently performed ulnar abduction.

Potential risk factors. The potential risk factors included personal factors and medical history, work history, and exposure to physical, psychosocial, and organizational work factors (table 1).

With respect to personal factors and medical history, details of weight and height were assessed using 
Table 1. Potential risk factors for de Quervain's disease (DQD) considered in the study and results of the univariate analysis. [OR=0dds ration; $95 \% \mathrm{Cl}=95 \%$ confidence interval; bold=P<0.20; NC=not calculated; $\mathrm{RPE}=$ rating perceived exertion]

\begin{tabular}{|c|c|c|c|c|c|c|c|c|c|c|c|c|c|c|c|}
\hline \multirow[t]{2}{*}{ Risk factors } & \multicolumn{5}{|c|}{ Total $(\mathrm{N}=3710)$} & \multicolumn{5}{|c|}{ Men $(\mathrm{N}=2161)$} & \multicolumn{5}{|c|}{ Women $(\mathrm{N}=1549)$} \\
\hline & $\mathrm{N}_{\text {sample }}$ & $N_{D Q D}$ & $\mathrm{OR}{ }^{\mathrm{a}}$ & $\begin{array}{l}95 \% \\
\mathrm{Cl} \text { a }\end{array}$ & $\begin{array}{l}\mathrm{P}- \\
\text { value }\end{array}$ & $\mathrm{N}_{\text {sample }}$ & $\mathrm{N}_{\mathrm{DQD}}$ & $\mathrm{OR}$ & $95 \% \mathrm{Cl}$ & $\begin{array}{l}\mathrm{P}- \\
\text { value }\end{array}$ & $\mathrm{N}_{\text {sample }}$ & $\mathrm{N}_{\mathrm{DQD}}$ & $\mathrm{OR}$ & $95 \% \mathrm{Cl}$ & $\begin{array}{l}\mathrm{P}- \\
\text { value }\end{array}$ \\
\hline \multicolumn{16}{|l|}{ Personal factors and medical history } \\
\hline Age (1-year increase) & & & 1.0 & $1.0-1.1$ & 0.002 & & & 1.0 & $1.0-1.1$ & 0.418 & & & 1.1 & $1.0-1.1$ & 0.002 \\
\hline Body mass index $\left(\mathrm{kg} / \mathrm{m}^{2}\right)^{\mathrm{b}}$ & 1378 & 22 & 2.0 & $1.1-3.7$ & 0.021 & 930 & 7 & 1.5 & $0.5-4.5$ & 0.454 & 448 & 15 & 2.3 & $1.1-4.7$ & 0.023 \\
\hline Diabetes mellitus (yes/no) & 61 & 1 & 1.5 & $0.2-11.4$ & 0.678 & 40 & 1 & 4.5 & $0.6-35.3$ & 0.154 & 21 & 0 & NC & & \\
\hline Thyroid disorders (yes/no) & 135 & 6 & 3.0 & $1.2-7.3$ & 0.016 & 33 & 0 & NC & & & 102 & 6 & 3.4 & $1.4-8.5$ & 0.009 \\
\hline \multicolumn{16}{|l|}{ Occupational factors } \\
\hline \multicolumn{16}{|l|}{ Current occupational category } \\
\hline $\begin{array}{l}\text { Managers, professionals, } \\
\text { technicians }\end{array}$ & 1133 & 4 & 1 & & 0.011 & 763 & 1 & 1 & & 0.289 & 370 & 3 & 1 & & 0.054 \\
\hline Low-grade white-collar worker & 986 & 16 & 2.6 & $0.9-8.0$ & & 187 & 1 & 4.1 & $0.3-65.8$ & & 799 & 15 & 2.3 & $0.7-8.1$ & \\
\hline Skilled blue-collar worker & 943 & 12 & 5.5 & $1.7-17.6$ & & 832 & 7 & 6.5 & $0.8-52.7$ & & 111 & 5 & 5.8 & $1.4-24.5$ & \\
\hline Unskilled blue-collar worker & 643 & 13 & 5.1 & $1.7-15.9$ & & 377 & 4 & 8.2 & $0.9-73.3$ & & 266 & 9 & 4.3 & $1.1-16.0$ & \\
\hline \multicolumn{16}{|l|}{$\begin{array}{l}\text { Length of service in the current } \\
\text { job (years) }\end{array}$} \\
\hline$<1$ & 455 & 4 & 1 & & 0.898 & 270 & 0 & NC & & & 185 & 4 & 1 & & 0.754 \\
\hline $1-2$ & 591 & 8 & 1.5 & $0.4-5.0$ & & 334 & 5 & & & & 257 & 3 & 0.5 & $0.1-2.4$ & \\
\hline $3-10$ & 1238 & 14 & 1.3 & $0.4-3.9$ & & 725 & 2 & & & & 513 & 12 & 1.1 & $0.3-3.4$ & \\
\hline$>10$ & 1389 & 18 & 1.5 & $0.5-4.4$ & & 809 & 6 & & & & 580 & 12 & 1.0 & $0.3-3.0$ & \\
\hline \multicolumn{16}{|l|}{ Factors related to work organization } \\
\hline Paced work (yes/no) & 383 & 4 & 0.9 & $0.3-2.5$ & 0.836 & 235 & 0 & NC & & & 148 & 4 & 1.4 & $0.5-3.9$ & 0.575 \\
\hline $\begin{array}{l}\text { Work pace dependent on } \\
\text { automatic rate (yes/no) }\end{array}$ & 400 & 3 & 0.7 & $0.2-2.1$ & 0.479 & 258 & 1 & 0.7 & $0.1-5.1$ & 0.681 & 142 & 2 & 0.7 & $0.2-2.8$ & 0.564 \\
\hline $\begin{array}{l}\text { Work pace dependent on } \\
\text { technical organization (yes/no) }\end{array}$ & 742 & 14 & 2.7 & $1.4-5.2$ & 0.004 & 554 & 7 & 4.0 & $1.3-12.5$ & 0.019 & 188 & 7 & 2.2 & $0.9-5.1$ & 0.081 \\
\hline $\begin{array}{l}\text { Work pace dependent on } \\
\text { customers' demands (yes/no) }\end{array}$ & 1643 & 17 & 0.7 & $0.4-1.3$ & 0.259 & 928 & 6 & 1.1 & $0.4-3.3$ & 0.860 & 715 & 11 & 0.6 & $0.3-1.2$ & 0.150 \\
\hline $\begin{array}{l}\text { Work pace dependent on the } \\
\text { colleagues' work (yes/no) }\end{array}$ & 1109 & 14 & 1.2 & $0.6-2.2$ & 0.616 & 698 & 4 & 1.0 & $0.3-3.3$ & 0.995 & 411 & 10 & 1.3 & $0.6-2.7$ & 0.550 \\
\hline $\begin{array}{l}\text { Work pace dependent on } \\
\text { quantified targets(yes/no) }\end{array}$ & 1729 & 24 & 1.5 & $0.8-2.8$ & 0.167 & 1,122 & 9 & 2.0 & $0.6-6.5$ & 0.250 & 607 & 15 & 1.4 & $0.7-2.8$ & 0.374 \\
\hline $\begin{array}{l}\text { Job/task rotation ( } \geq 1 \text { job } \\
\text { rotation per week) (yes/no) }\end{array}$ & 1350 & 19 & 1.4 & $0.8-2.6$ & 0.297 & 815 & 7 & 1.8 & $0.6-5.3$ & 0.306 & 535 & 12 & 1.2 & $0.6-2.6$ & 0.578 \\
\hline $\begin{array}{l}\text { Work with temporary workers } \\
\text { (yes/no) }\end{array}$ & 1106 & 18 & 1.6 & $0.9-2.9$ & 0.147 & 639 & 4 & 1.1 & $0.3-3.4$ & 0.929 & 467 & 14 & 1.8 & $0.9-3.7$ & 0.099 \\
\hline High visual demand (yes/no) & 2379 & 33 & 1.5 & $0.8-2.8$ & 0.262 & 1,371 & 12 & 6.8 & $0.9-52.6$ & 0.065 & 1008 & 21 & 1.0 & $0.5-2.1$ & 0.963 \\
\hline Overtime hours (yes/no) & 2186 & 26 & 1.1 & $0.6-1.9$ & 0.871 & 1,376 & 11 & 3.0 & $0.7-13.6$ & 0.154 & 810 & 15 & 0.8 & $0.4-1.6$ & 0.466 \\
\hline $\begin{array}{l}\text { No prior knowledge of the } \\
\text { workload (yes/no) }\end{array}$ & 366 & 3 & 0.9 & $0.3-2.9$ & 0.837 & 288 & 2 & 1.2 & $0.3-5.3$ & 0.832 & 78 & 1 & 0.6 & $0.1-4.5$ & 0.619 \\
\hline $\begin{array}{l}\text { Work pace dependent on } \\
\text { permanent controls (yes/no) }\end{array}$ & 936 & 14 & 1.5 & $0.8-2.8$ & 0.253 & 575 & 6 & 2.7 & $0.9-8.4$ & 0.088 & 361 & 8 & 1.1 & $0.5-2.5$ & 0.829 \\
\hline
\end{tabular}

Working postures and biomechanical constraints

\begin{tabular}{|c|c|c|c|c|c|c|c|c|c|c|c|c|c|c|c|}
\hline $\begin{array}{l}\text { High repetitiveness ( } \geq 4 \text { hours } \\
\text { per day) (yes/no) }\end{array}$ & 958 & 22 & 2.4 & $1.3-4.4$ & 0.003 & 477 & 3 & 1.1 & $0.3-3.8$ & 0.940 & 481 & 19 & 3.3 & $1.6-6.7$ & 0.001 \\
\hline $\begin{array}{l}\text { High physical demand (RPE } \\
\text { Borg scale } \geq 13 \text { ) (yes/no) }\end{array}$ & 1856 & 31 & 2.7 & $1.4-5.2$ & 0.003 & 1,168 & 12 & 10.2 & $1.3-78.5$ & 0.026 & 688 & 19 & 2.0 & $1.0-4.1$ & 0 . \\
\hline $\begin{array}{l}\text { Repeated or sustained move- } \\
\text { ment turning driving screw } \\
\text { ( } \geq 2 \text { hours per day) (yes/no) }\end{array}$ & 534 & 16 & 5.9 & $3.0-11.5$ & $<0.001$ & 443 & 8 & 6.3 & $2.0-19.2$ & 0.001 & 91 & 8 & 5.7 & $2.5-13.1$ & \\
\hline $\begin{array}{l}\text { Repeated or sustained wrist } \\
\text { bending ( } \geq 2 \text { hours per day) } \\
\text { (yes/no) }\end{array}$ & 1236 & 29 & 3.8 & $2.1-7.1$ & $<0.001$ & 749 & 9 & 4.2 & $1.3-13.7$ & 0.017 & 487 & 20 & 3.7 & $1.8-7.6$ & $<0$. \\
\hline $\begin{array}{l}\text { Holding tools or objects in a } \\
\text { pinch grip ( } \geq 4 \text { hours per day) } \\
\text { (yes/no) }\end{array}$ & 297 & 7 & 2.0 & $0.9-4.5$ & 0.095 & 158 & 1 & 1.1 & $0.1-8.1$ & 0.096 & 139 & 6 & 2.4 & $1.0-5.9$ & 0.060 \\
\hline $\begin{array}{l}\text { Precise finger movements } \\
\text { ( } \geq 2 \text { hours per day) (yes/no) }\end{array}$ & 1665 & 1 & 2.8 & $1.5-5.4$ & 0.001 & 1,003 & 11 & 6.3 & $1.4-28.6$ & 0.017 & 662 & 20 & 2.2 & $1.1-4.6$ & \\
\hline
\end{tabular}


Table 1. Continued

\begin{tabular}{|c|c|c|c|c|c|c|c|c|c|c|c|c|c|c|c|}
\hline \multirow[t]{2}{*}{ Risk factors } & \multicolumn{5}{|c|}{ Total $(\mathrm{N}=3710)$} & \multicolumn{5}{|c|}{ Men $(\mathrm{N}=2161)$} & \multicolumn{5}{|c|}{ Women $(\mathrm{N}=1549)$} \\
\hline & $\mathrm{N}_{\text {sample }}$ & $\mathrm{N}_{D Q D}$ & $\mathrm{OR}^{\mathrm{a}}$ & $\begin{array}{l}95 \% \\
\mathrm{Cl}^{\mathrm{a}}\end{array}$ & $\begin{array}{c}\mathrm{P}- \\
\text { value }\end{array}$ & $\mathrm{N}_{\text {sample }}$ & $\mathrm{N}_{\mathrm{DQD}}$ & $\mathrm{OR}$ & $95 \% \mathrm{Cl}$ & $\begin{array}{c}\mathrm{P}- \\
\text { value }\end{array}$ & $\mathrm{N}_{\text {sample }}$ & $\mathrm{N}_{\mathrm{DQD}}$ & OR & $95 \% \mathrm{Cl}$ & $\begin{array}{l}\mathrm{P}- \\
\text { value }\end{array}$ \\
\hline $\begin{array}{l}\text { Pressing with the base of } \\
\text { the palm ( } \geq 2 \text { hours per day) } \\
\text { (yes/no) }\end{array}$ & 294 & 7 & 3.2 & $1.4-7.4$ & 0.007 & 238 & 3 & $\begin{array}{ll}3 \quad 2.4 \\
\end{array}$ & $0.7-8.9$ & 0.180 & 56 & 4 & 4.0 & $1.4-11.8$ & 0.012 \\
\hline $\begin{array}{l}\text { Use of handtools ( } \geq 2 \text { hours } \\
\text { per day) (yes/no) }\end{array}$ & 1711 & 23 & 1.5 & $0.8-2.8$ & 0.168 & 1,159 & 9 & $9 \quad 1.9$ & $0.6-6.3$ & 0.275 & 552 & 14 & 1.4 & $0.7-2.8$ & 0.357 \\
\hline $\begin{array}{l}\text { Use of vibrating handtools } \\
\text { ( } \geq 2 \text { hours per day) (yes/no) }\end{array}$ & 469 & 8 & 2.6 & $1.2-6.0$ & 0.021 & 407 & 5 & $5 \quad 2.7$ & $0.9-8.3$ & 0.083 & 62 & 3 & 2.5 & $0.8-8.6$ & 0.133 \\
\hline $\begin{array}{l}\text { Exposure to cold temperatures } \\
\text { ( } \geq 4 \text { hours per day) (yes/no) }\end{array}$ & 220 & 5 & 2.3 & $0.9-5.9$ & 0.086 & 149 & 4 & $4 \quad 6.1$ & 1.9-20.1 & 0.003 & 71 & 1 & 0.7 & $0.1-4.9$ & 0.689 \\
\hline $\begin{array}{l}\text { Keying and computer work } \\
\text { ( } \geq 4 \text { hours per day) (yes/no) }\end{array}$ & 1024 & 8 & 0.4 & $0.2-0.9$ & 0.030 & 432 & 0 & $0 \quad \mathrm{NC}$ & & & 592 & 8 & 0.5 & $0.2-1.2$ & 0.121 \\
\hline $\begin{array}{l}\text { Wearing gloves ( } \geq 4 \text { hours per } \\
\text { day) (yes/no) }\end{array}$ & 584 & 13 & 2.5 & $1.3-4.8$ & 0.006 & 388 & 4 & $4 \quad 2.0$ & $0.6-6.6$ & 0.240 & 196 & 9 & 2.8 & $1.3-6.1$ & 0.011 \\
\hline \multicolumn{16}{|l|}{ Psychosocial factors at work } \\
\hline $\begin{array}{l}\text { High psychological demand } \\
\text { (yes/no) }\end{array}$ & 1815 & 23 & 1.1 & $0.6-2.0$ & 0.739 & 1,050 & 8 & $8 \quad 2.1$ & $0.6-6.9$ & 0.233 & 765 & 15 & 0.9 & $0.4-1.8$ & 0.718 \\
\hline Low skill discretion (yes/no) & 2016 & 27 & 1.1 & $0.6-1.9$ & 0.862 & 1,060 & 7 & $7 \quad 1.2$ & $0.4-3.6$ & 0.750 & 956 & 20 & 1.0 & $0.5-2.1$ & 0.998 \\
\hline Low decision authority (yes/no) & 1276 & 20 & 1.3 & $0.7-2.4$ & 0.342 & 652 & 2 & 20.4 & $0.1-1.9$ & 0.254 & 624 & 18 & 1.9 & $0.9-3.9$ & 0.074 \\
\hline $\begin{array}{l}\text { Low supervisor support } \\
\text { (yes/no) }\end{array}$ & 1427 & 20 & 1.3 & $0.7-2.3$ & 0.430 & 850 & 7 & $7 \quad 1.8$ & $0.6-5.3$ & 0.312 & 577 & 13 & 1.1 & $0.5-2.3$ & 0.781 \\
\hline Low coworker support (yes/no) & 708 & 12 & 1.5 & $0.8-2.9$ & 0.241 & 406 & 4 & $\begin{array}{ll}4 & 1.9\end{array}$ & $0.6-6.2$ & 0.290 & 302 & 8 & 1.3 & $0.6-3.0$ & 0.475 \\
\hline
\end{tabular}

a Adjusted for gender.

b Overweight-obesity (BMI $\geq 25)$

a self-administered questionnaire; details on diabetes mellitus, and thyroid disorders were collected during the physical examination. Work history and exposure to occupational risk factors were assessed with a self-administered questionnaire including information on the characteristics of the job and tasks, work organization, and the main potential risk factors for upper-limb MSD. Biomechanical risk factors for DQD were defined and quantified according to the European consensus criteria document (20), except for physical workload, which was assessed using the rating perceived-exertion Borg scale (20-RPE) graduated from 6 ("very, very light") to 20 ("maximal exertion"). Postures of the hand and pinching movements were assessed using picture forms to facilitate workers' understanding. Response categories were presented on a 4-level Likert-type scale, as follows: "never or practically never, rarely" ( $<2$ hours per day), "often" ( $2-4$ hours per day) and "always" ( $>4$ hours per day) and dichotomized to 2 or 4 hours. Information on the work organization, time schedule, and daily job rotation was collected. Exposure to stress at work was appraised with reference to the demand-control-support model using the validated French version of the job content questionnaire (22). The questionnaires were filled out by workers just before the medical examination and checked by the OP at the beginning of the examination. The response rate to all questions was above $97 \%$.

\section{Statistical analysis}

The outcome was defined by subject, and thus bilateral cases of DQD counted as one disorder, not two. The list of independent variables considered in the analyses comprised variables known or suspected to be potential risk factors for hand-wrist disorders on the basis of epidemiological and ergonomic studies (table 1) (14-17, 23, 24).

As there were very few cases of DQD among men, multivariate analysis were only performed in the whole sample and among women using binary logistic regression modeling, which followed a three-level process consisting of univariate models (stage 1), group multivariate models (stage 2), and final multivariate model (stage 3). All models included age and gender (if necessary) as possible confounders.

At stage 1, univariate analyses were performed with each of the potential explanatory variables as independent variables and DQD as the dependent variable. Non-significant variables $(\mathrm{P}>0.20)$ were excluded from further analyses. During stage 2, the independent variables not excluded in stage 1 were grouped into the five groups of potential determinants (see table 1), namely, personal factors and medical history, work history, factors related to work organization, postural and biomechanical constraints, and psychosocial factors at work. Backward multivariate logistic regression models were then performed for each of the five groups of 
variables [except age and (if appropriate) gender, which were forced into all models]. Non-significant variables $(\mathrm{P}>0.10)$ after this stage were excluded from further analyses. During stage 3, final multivariate logistic regression analyses were performed using all remaining variables after stages 1 and 2 . If a subject was missing for any variables included in the final model for the whole population, that subject was excluded from the analysis. Non-significant variables $(\mathrm{P}>0.05)$ were excluded. All analyses were performed with the SAS statistical software package, version 9.2 (SAS Institute Inc, Cary, NC, USA).

\section{Results}

There were 45 subjects ( 32 women and 13 men) with DQD (of these, 5 subjects had a bilateral condition), and a total of 50 cases of DQD were diagnosed. The right hand was involved in 23 cases, the left hand in 17 cases, and both in 5 cases. The prevalence rates of uni- or bilateral DQD for the whole, male, and female working populations were $1.2 \%$ (95\% CI $0.9-1.6), 0.6 \%$ (95\% CI $0.3-0.9$ ) and $2.1 \%$ (95\% CI 1.4-2.8), respectively. Higher prevalence was observed among skilled $(0.8 \%$ of men and $4.5 \%$ of women) and unskilled (1.1\% of men and $3.4 \%$ of women) blue-collar workers.

DQD was often associated with carpal tunnel syndrome (33 \% of cases) or rotator cuff syndrome (29\%), and more rarely with lateral epicondylitis (7\%), ulnar tunnel syndrome (4\%) or flexor-extensor peritendinitis/ tenosynovitis of the forearm-wrist region $(2 \%)$.

Table 1 presents results for the whole sample (adjusted for gender) and men and women separately. Univariate analyses showed that numerous biomechanical factors, but only a few organizational and psychosocial factors, were associated with DQD.

The multivariate analyses for the whole sample (table 2) showed a linear increase in the risk of DQD of 1.1 for 1-year increase in age (between 20-59 years). The association between DQD and length of service in the current job was not statistically significant. Among the personal factors studied, female gender was strongly associated with DQD [odds ratio (OR) 4.9] after adjustment for other potential confounding factors. The risk of DQD was not associated with overweight and obesity.

Among the factors related to the work organization studied, workpace dependent on the technical organization was highlighted in the final model (OR 2.0), as were two work-related biomechanical factors: repeated or sustained wrist bending in extreme postures for $>2$ hours per day (OR 2.6) and repeated movements associated with the twisting or driving of screws for $>2$ hours per day (OR 3.4). The association with high repetitiveness of the task (OR 1.8) was at the limit of the statistical level of significance. No significant relationships were observed for pinching or use of vibrating hand tools, computer, or keyboard. High physical demand and exposure to cold were not related to DQD. No significant association was found with psychosocial factors of stress at work. The personal risk factors highlighted by the multivariate model of DQD among women were age (OR 1.1 for 1-year increase in age) and the occurrence of thyroid disorders (OR 2.9). The work-related factors were repeated or sustained wrist bending (OR 2.3) and repeated movements associated with the twisting or driving of screws (OR 3.2), as in the model for the whole sample, and the high repetitiveness of the task (OR 2.5).

\section{Discussion}

The prevalence of the DQD was $1.2 \%$ in this large representative sample of the working population, and higher among women and blue-collar workers. The study showed the multifactorial origin of DQD and

Table 2. Multivariate model of risk factors for de Quervain's disease in the whole working population and in women. [OR=0dds ratio; $95 \%$ $\mathrm{Cl}=95 \%$ confidence interval.]

\begin{tabular}{|c|c|c|c|c|c|c|c|c|c|c|c|c|}
\hline & \multicolumn{6}{|c|}{ Total $(\mathrm{N}=3528)$} & \multicolumn{6}{|c|}{ Women $(\mathrm{N}=1503)$} \\
\hline & $\mathrm{N}_{\text {sample }}$ & $\mathrm{N}$ & $\%$ & $\mathrm{OR}$ & $95 \% \mathrm{Cl}$ & $P$ value & $\mathrm{N}_{\text {sample }}$ & $\mathrm{N}$ & $\%$ & $\mathrm{OR}$ & $95 \% \mathrm{Cl}$ & $P$ value \\
\hline Gender (female) & 1460 & 30 & 2.1 & 4.9 & $2.4-10.1$ & $<0.001$ & & & & & & \\
\hline Age (1 year) & & & & 1.1 & $1.0-1.1$ & 0.001 & & & & 1.1 & $1.0-1.1$ & 0.005 \\
\hline Thyroid disorders & & & & & & & 99 & 6 & 6.1 & 2.9 & $1.1-7.6$ & 0.027 \\
\hline Workpace dependent on technical organization & 730 & 14 & 1.9 & 2.0 & $1.0-4.0$ & 0.045 & & & & & & \\
\hline High repetitiveness ( $\geq 4$ hours per day) & 912 & 21 & 2.3 & 1.8 & $0.9-3.4$ & 0.093 & 471 & 19 & 4.0 & 2.5 & $1.1-5.3$ & 0.022 \\
\hline $\begin{array}{l}\text { Repeated or sustained movement turning driving } \\
\text { screw ( } \geq 2 \text { hours per day) }\end{array}$ & 506 & 15 & 3.0 & 3.4 & $1.7-7.1$ & 0.001 & 88 & 8 & 9.1 & 3.2 & $1.3-7.8$ & 0.013 \\
\hline $\begin{array}{l}\text { Repeated or sustained wrist bending ( } \geq 2 \text { hours } \\
\text { per day) }\end{array}$ & 1190 & 28 & 2.4 & 2.6 & $1.3-5.3$ & 0.010 & 476 & 20 & 4.2 & 2.3 & $1.0-5.1$ & 0.044 \\
\hline
\end{tabular}


highlighted a limited number of personal and workrelated risk factors.

The prevalence of DQD observed in this working population was close to that estimated in the British general population of working age $(0.5 \%$ of men and $1.3 \%$ of women) (25). However, our estimates were lower than those reported for highly exposed blue-collar workers in automotive plants $(4,8,11)$ and the meatprocessing and manufacturing industries $(7,10,15)$.

Among the potential personal factors studied, female gender was the main factor associated with DQD in our population. This is consistent with the epidemiological literature $(4,12,13,26,27)$. The higher risk of DQD among women could reflect both biological predispositions (sex effect) and greater exposure to biomechanical repetitive work-related constraints (gender-effect) (28). Previous results regarding all upper-extremity MSD (21) suggest that the gender difference more probably reflects differences in exposure to constraints at work than physiological differences (eg, body size). In most cases, women are more often exposed to tasks requiring dexterity and rapid and repetitive movements of the thumb and fingers because of the gender division of work (13).

Advancing age increased the risk of DQD, which is consistent with the medical literature reporting "normal" degenerative changes in ageing tendons and a higher risk of DQD among workers $>40$ years of age $(12,15,29)$. However, age seemed to play a smaller role in DQD than in other upper-extremity MSD in this working population, in particular rotator cuff syndrome (21). No clear association was found between length of service and DQD, but age and length of service were highly correlated, making it difficult to disentangle the role of age from the effects of cumulative exposure to occupational hazards in the interpretation of our results.

Contrary to some studies $(12,15)$, no association was found with abnormal weight and diabetes mellitus in the multivariate models. The low severity of the cases of DQD compared to cases recruited in orthopedic or rheumatologic clinics could explain this result, as could the lack of statistical power of the study.

Our study shows a strong and consistent association between DQD and sustained or repeated wrist bending and twisting. This confirms results for hand-wrist tendinitis observed among workers highly exposed to wrist flexion/extension (16), pronation/supination (13) and, more generally, sustained or repeated postures of the hand and wrist $(13,25,30,31,32)$. The influence of postural factors on the risk of DQD seems to be higher and more significant for DQD than for the other upper-extremity MSD in this working population (21). However, we cannot exclude the possibility that some workers suffering from DQD overrated their exposure to awkward working postures (33). Exposure to workpace dependent on the technical organization, which could represent a measure of the repetitiveness of the task, increased the risk of DQD. This agrees with previous studies on hand-wris tendonitis $(12,13,16,31,34,35)$. The multifactorial nature of disorders involving several biomechanical and organizational factors is coherent with the literature reporting higher risk of hand-wrist tendinitis for combined exposure to work-related risk factors $(13,32)$. Contrary to some studies, no association was found for the physical demands of the task, forceful exertion $(12,13,31,34,35)$ or exposure to hand-wrist vibrations (31). DQD was not associated with computer use in our study, although a high incidence of DQD has been reported in a large cohort of computer users (36).

Using the demand-control-support model of stress at work, no significant relationship was found for stress, contrary to the findings in the same population for upper-extremity MSD overall (21) or rotator cuff syndrome in particular. Consequently, this could not be explained by the methodology used, except for a lack of statistical power due to the small number of cases of DQD diagnosed. The results in the literature are inconsistent, since some studies of wrist tendinitis reported an association with psychosocial factors, such as low social support or psychosocial stress (34), and others not $(17,24)$.

The large sample of workers was characterized by wide variations in activity sectors and occupations, representing a broad range of both physical and mental occupational tasks. Its good representativeness in relation to the regional workforce allows greater generalization of the results than epidemiological studies conducted in selected occupational populations. Few workers failed to participate but, due to the cross-sectional design of the study, a "healthy worker effect" could have occurred and may have caused an underestimation of the estimates of risk. Outcomes were assessed clinically by trained physicians using a rigorous physical examination, including standardized provocation tests, and allowing more accurate diagnosis of DQD than the questionnaire. Finkelstein's test is widely accepted and used by clinicians for the diagnosis of DQD (20). However, it lacks specificity and may be positive in cases of osteoarthritis of the wrist or first carpometaphalangeal joint and flexor/extensor hand-wrist tendonitis (37), which frequently overlap with $\operatorname{DQD}(8,25)$. We cannot therefore exclude the possibility that some cases diagnosed as DQD were symptomatic of osteoarthritis or flexor/extensor hand-wrist tendinitis in the absence of imaging of the wrist.

In contrast to several studies, our survey allowed assessment of the risk factors for specific MSD defined by objective criteria in a diversified working population. Length of service for most workers was longer than the previous 12-month period chosen for the assessment of work exposure, and this reduces exposure classification errors. The main personal and occupational potential risk 
factors for DQD described in the literature were taken into account. While the potential determinants of DQD are numerous, few studies involving workers have taken personal, physical, and psychosocial factors into account together. Non-work activity, such as housework, leisure and sports, were not assessed although they may increase the risk of DQD. Although residual confounding factors are always possible, we believe that we had information on the most important confounders. As much as possible, standardized and validated instruments were used to reduce exposure classification errors. For example, wrist postures were presented in picture form to facilitate workers' understanding and increase the validity of posture self-assessment. The recall period of the last 12 months chosen limits recall errors in self-reported exposure (38). The most serious drawback to exposure assessment in this study was that occupational risk factors were assessed through a self-administered questionnaire (33).

In conclusion, the study showed that personal and work-related factors were strongly associated with clinically-diagnosed DQD. Among the work-related factors for $\mathrm{DQD}$, motions involving the wrist had a more significant role than other physical factors. Mechanical exposure should therefore be an important target of strategies for the prevention of $\mathrm{DQD}$ in working populations.

\section{Acknowledgement}

We are grateful to the occupational physicians involved in the sentinel network: Doctors Abonnat, Banon, Bardet, Benetti, Becquemie, Bertin, Bertrand, Bidron, Biton, Bizouarne, Boisse, Bonamy, Bonneau, Bouguer, Bouguer-Diquelou, Bourut-Lacouture, Breton, Caillon, Cesbron, Chisacoff, Chotard, Compain, CoquinGeogeac, Cordes, Couet, Coutand, Daniellou, Darcy, Davenas, De Lescure, Delansalut, Dupas, Evano, Fache, Fontaine, Frampas-Chotard, Guiller, Guillimin, Harinte, Harrigan, Hervio, Hirigoyen, Jahan, Joliveau, Jube, Kalfon, Laine-Colin, Laventure, Le Dizet, Lechevalier, Leclerc, Ledenvic, Leroux, Leroy-Maguer, Levrard, Levy, Logeay, Lucas, Mallet, Martin, Mazoyer, Meritet, Michel, Migne-Cousseau, Moisan, Page, Patillot, Pinaud, Pineau, Pizzala, Plessis, Plouhinec, Raffray, Roussel, Russu, Saboureault, Schlindwein, Soulard, Thomson, Treillard, Tripodi.

The Pays de la Loire study received the approval of France's National Committee for Data Protection (CNIL: Commission Nationale Informatique et Liberté). The study was supported by the French Institute for Public Health Surveillance, Saint-Maurice, France (Grant 9/25/2002-5 "réseau expérimental de surveillance des troubles musculo-squelettiques") and the French National Research Agency (ANR-Grant SEST-06-36).
The authors declare no competing interests.

\section{References}

1. Moore JS. 1997. De Quervain's tenosynovitis: stenosing tenosynovitis of the first dorsal compartment. J Occup Med. 39:990-1002. doi:10.1097/00043764-199710000-00011.

2. Anderson SE. "Baby Wrist": MRI of an Overuse Syndrome in Mothers. AJR. 2004;182:719-24

3. Thompson AR, Plewes LW, Shaw EG. 1951. Peritendinitis crepitans and simple tenosynovitis: A clinical study of 544 cases in industry. Br J Ind Med. 8:150-60.

4. Bystrom $\mathrm{S}$ et al. Clinical disorders and pressure-pain threshold of the forearm and hand among automobile assembly line workers. J Hand Surg. 1995;20B:782-90. doi:10.1016/S02667681(95)80047-6.

5. Kurppa K, Viikari-Juntura E, Kuosma E, Huuskonen M, Kivi P. Incidence of tenosynovitis or peritendinitis and epicondylitis in a meat-processing factory. Scand J Work Environ Health. $1991 ; 17: 32-7$.

6. Luopajarvi T, Kuorinka I, Virolainen M, Holmberg M. Prevalence of tenosynovitis and and other injuries of the upper extremities in repetitive work. Scand J Work Environ Health. 1979;5(suppl):48-55.

7. McCormack RR Jr, Inman RD, Wells A, Wells A, Berntsen C, Imbus HR. Prevalence of tendinitis and related disorders of the upper extremity in a manufacturing workforce. J Rheumatol. 1990;17:958-64.

8. Gold JE, d'Errico A, Katz JN, Gore R, Punnett L. Specific and Non-Specific Upper Extremity Musculoskeletal Syndromes in Automobile Manufacturing Workers. Am J Indust Med. 2009;52:124-32. doi:10.1002/ajim.20653.

9. Roquelaure Y., Ha C., Leclerc A., Touranchet A, Sauteron M, Melchior M, et al. Epidemiological Surveillance of Upper Extremity Musculoskeletal Disorders in the Working Population: the French Pays de la Loire Study. Arthritis Rheum. 2006;55:765-78. doi:10.1002/art.22222.

10. Viikari-Juntura E. Neck and upper limb disorders among slaughterhouse workers. An epidemiologic and clinical study. Scand J Work Environ Health. 1983;9:283-90.

11. Zetterberg C, Ofverholm T. Carpal tunnel syndrome and other wrist/hand symptoms and signs in male and female car assembly workers. Int J Indust Ergon. 1999;23:193-204. doi:10.1016/S0169-8141(97)00054-1.

12. Wolf JM, Sturdivant RX, Owens BD. Incidence of de Quervain's Tenosynovitis in a Young, Active Population. J Hand Surg. 2009;34A:112-115.

13. Tanaka S, Petersen M, Cameron L. Prevalence and risks factors of tendinitis and related disorders of the distal upper extremity among U.S. workers: comparison to carpal tunnel syndrome. Am J Indust Med. 2001;39:328-35. doi:10.1002/10970274(200103)39:3<328::AID-AJIM1021>3.0.CO;2-I.

14. Armstrong TJ, Fine LJ, Goldstein SA, et al. Ergonomics 
considerations in hand and wrist tendinitis. J Hand Surg. 1987;12A:830-7.

15. Hagberg M, Silverstein B, Wells R, et al. Work related musculoskeletal disorders (WMSDs): a reference book for prevention. London: Taylor \& Francis, 1995.

16. Bernard BP. Musculoskeletal disorders and workplace factors. A critical review of epidemiologic evidence for work-related musculoskeletal disorders of the neck, upper-extremity, and low back. NIOSH, Cincinnati, 1997, DHHS (NIOSH) publication.

17. Malchaire J, Cock N, Vergracht S. Review of the factors associated with musculoskeletal problems in epidemiological studies. Int Arch Occup Environ Med. 2001;74:79-90. doi:10.1007/s004200000212.

18. Palmer KT, Harris CE, Coggon D. Compensating occupationally related tenosynovitis and epicondylitis: a literature review. Occup Med. 2007;57:67-74. doi:10.1093/ occmed/kq1127.

19. Ha C, Roquelaure Y, Leclerc A, et al.: Pays de la Loire network. Occup Environ Med. 2009;66:471-9. doi:10.1136/ oem.2008.042812.

20. Sluiter JK, Rest KM, Frings-Dresen MHV. Criteria document for evaluation of the work-relatedness of upper extremity musculoskeletal disorders. Scand J Work Environ Health. 2001;27(suppl.1):1-102.

21. Roquelaure $\mathrm{Y}, \mathrm{Ha} \mathrm{C}$, Rouillon C, Fouquet N, Leclerc A, Descatha A et al. Risk factors for upper-extremity musculoskeletal disorders in the working population. Arthritis Rheum. 2009;61:1425-34. doi:10.1002/art.24740.

22. Niedhammer I. Psychometric properties of the French version of the Karasek Job Content Questionnaire: a study of the scales of decision latitude, psychological demands, social support, and physical demands in the GAZEL cohort. Int Arch Occup Environ Health. 2002;75:129-44. doi:10.1007/s004200100270.

23. National research council. The National Academy of Sciences. Musculoskeletal Disorders and the Workplace: Low back and Upper Extremity musculoskeletal disorders. National Academy Press, Washington DC, 2001.

24. Bongers PM, Ijmker S, Van den Heuvel S, Blatter PM. Epidemiology of work related neck and upper limb problems: Psychosocial and personal risk factors (Part I) and effective intervention from a bio behavioural perspective. J Occup Rehab. 2006;16:279-302. doi:10.1007/s10926-006-9044-1.

25. Walker-Bone K, Palmer KT, Reading I, Coggon D, Cooper C. Prevalence and impact of musculoskeletal disorders of the upper limb in the general population. Arthritis Rheum. 2004;51:642-51. doi:10.1002/art.20535.

26. Piligian G, Herbert R, Hearns M, Dropkin J, Landsbergis P, Cherniack M. Evaluation and Management of Chronic Work-Related Musculoskeletal Disorders of the Distal
Upper Extremity. Am J Indust Med. 2000;37:75-93. doi:10.1002/(SICI)1097-0274(200001)37:1<75::AIDAJIM7>3.0.CO;2-4.

27. Walker-Bone KE, Palmer KT, Reading I, Cooper C. Soft-Tissue Rheumatic Disorders of the Neck and Upper Limb: Prevalence and Risk Factors. Seminars in Arthritis and Rheumatism. 2003;3:185-203. doi:10.1016/S0049-0172(03)00128-8.

28. Silverstein B, Fan ZJ, Smith CK, Bao S, Howard N, Spielholz $\mathrm{P}$, et al. Gender adjustment or stratification in discerning upper extremity musculoskeletal disorder risk? Scand J Work Environ Health. 2009;35:113-26.

29. Latko WA, Armstrong TJ, Franzblau A, Ulin SS, Werner RA, Albers JW. Cross-Sectional Study of the Relationship Between Repetitive Work and the Prevalence of Upper Limb Muskuloskeletal Disorders. Am J Indust Med. 1999;36:248 59. doi:10.1002/(SICI)1097-0274(199908)36:2<248::AIDAJIM4>3.0.CO;2-Q.

30. Sheon RP, Moskowitz RW, Goldberg VM. Soft tissue rheumatic pain. Recognition, management, and prevention. New York, Williams \& Wilkins, 1996.

31. Barr AE, Barbe MF, Clark BD. Work-related musculoskeleta disorders of the hand and wrist : epidemiology, pathophysiology, and sensorimotor changes. J Orthop Sports Phys Ther. 2004;34:610-27.

32. Leclerc A, Landre MF, Chastang JF, Niedhammer I, Roquelaure Y. Carpal tunnel syndrome and work organisation in repetitive work: a cross sectional study in France. Occup Environ Med. 1998;55:180-7. doi:10.1136/oem.55.3.180.

33. Walker-Bone $\mathrm{K}$, Cooper C. Hard work never hurt anyone: or did it? a review of occupational associations with soft tissue musculoskeletal disorders of the neck and upper limb. Ann Rheum Dis. 2005;64:1391-6. doi:10.1136/ard.2003.020016.

34. Thomsen JF. Risk factors for hand- wrist disorders in repetitive work. Occup Environ Med. 1994;64:527-533. doi:10.1136/ oem.2005.021170.

35. Palmer KT. Regional musculoskeletal conditions: pain in the forearm, wrist and hand. Best Pract Res Clin Rheumatol. 2003;17(1):113-35. doi:10.1016/S1521-6942(02)00100-6.

36. Gerr F, Marcus M, Ensor C, Kleinbaum D et al. A prospective study of computer users: I. Study design and incidence of musculoskeletal symptoms and disorders. Am J Ind Med. 2002;41(4):221-35. doi:10.1002/ajim.10066.

37. Harrington JM, Carter JT, Birrel L, Gompertz D. Surveillance case definitions for work related upper limb pain syndromes. Occup Environ Med. 1998;55:264-71. doi:10.1136/ oem.55.4.264.

38. D'errico A, Gore R, Gold JE, Parks JS, Punnett L. Medium- and long-term reproducibility of self-reported exposure to physical ergonomics factors at work. Appl Ergon. 2007;38:167-75. doi:10.1016/j.apergo.2006.03.002

Received for publication: 23 July 2010 